\title{
CHILDRAN'S DRAWING OF HUMAN FIGURE ANALISIS
}

UDC 741:159.942-053.2(049.5)

\author{
Salko Pezo ${ }^{1}$
}

Teaching Faculty University of Džemal Bijedić, Mostar

Received: 13.04.2011

Accepted: 26.05.2011

\begin{abstract}
:
Beside speech, that helps children to express their feelings and experiences, establish relations with people, the drawing is one of the most truthful ways of its expression. In this paper the results of pleasant and unpleasant emotions among children through drawing of human figure are presented. The survey is conducted on 634 children, and the results indicate that there is difference in expressing negative emotions between boys and girls, while at expressing pleasant emotions the results are similar.
\end{abstract}

Key words: Children's art expression, pleasant and unpleasant emotions, Human figure

\section{INTRODUCTION}

Children art expression is "one of the basic form of children's expression and one of the most important needs of children" (Pedagoška enciklopedija, 1989).

Drawing and painting are one of the basics and important types of expression of psychic life of human. Beside speech that helps children to express their feelings and experiences, establish relations with people, the drawing is one of the most truthful ways of its expression. About children drawing, Stern says: "The children want to show something by its drawing, but not to paint the reality. Long lines are symbol for legs and arms and circles presents the head and eyes" (Pogačnik-Tolčić, 1964).

For a child the drawing is not the art but the way of expression. Art experts and psychics examine the characteristics of form and style of children's graphical expression at specific periods of psychic development, where they examine spontaneous drawing and the thematic of drawing in specific development periods. The thematic of graphical expression is researched theoretical, practical and for psycho diagnostic point of view.

1 Correspodence to:

Salko Pezo, PhD, Teaching Faculty University of Džemal Bijedić, Mostar

Univerzitetski Kampus, 88104 Mostar, Bosnia and Herzegovina,

Phone: +38736570993

E-mail: nf@unmo.ba 
The child is honest while drawing, it creates directly, with enthusiasm. Its expression means are simple, naïve but convincing, despite they are given without skills. The drawing enables us to enter their psychical life and establish the difference between child and adult.

According to emotional hierarchy, the figures on children drawing get adequate place and the size on paper format.

The perspectives manifests that with its meaning tell about love and closeness with dear persons (iconographic, multi perspective, vertical, reverse), then transparent shows and action in the movement. During drawing activities the child thinks and reacts emotively on reality, environment, which results by self understanding of world, things, figures etc.

The world, environment, person and event acceptation is at certain way experiencing of art expression of child, which represents the basic for interpretation and understanding of children art.

The aim of this paper was to establish the difference among emotion expression at boys and girls through the analysis of children art expression of human figure.

\section{METODS}

\section{Sampling}

The research is conducted on sample of 634 children, both sexes, age between 7 and 11 years. Their drawings of human shape are analyzed.

\section{Variable}

For this research the variable of human figure presence is analyzed at expression of pleasant and unpleasant emotions in children drawings.

\section{Data Analysis Processes}

In realization of survey the method of theoretical analysis and synthesis is used, as well as descriptive-comparative method and work on documentation.

By descriptive analysis, the primary statistical indicators are calculated on which basis the statistical analysis has been done. The hypothesis testing is done by $\mathrm{x}^{2}$ test.

\section{RESULTS AND DISCUSSION}

By analysis of children's drawing of human figure, the frequencies of pleasant emotions (joy, satisfaction, motivation, encouragement, will for work) and unpleasant emotions (sadness, disturbance, fear, toughness, non motivation, aggressiveness, pliability, disorientation) are evaluated. The drawings of 342 girls and 292 boys were analyzed.

Table 1. Drawings of human figure

\begin{tabular}{|c|c|c|c|c|c|c|}
\hline & \multicolumn{3}{|c|}{ Unpleasant emotions } & \multicolumn{3}{|c|}{ Pleasant emotions } \\
\hline & $\begin{array}{c}\text { Human } \\
\text { figures } \\
\text { present }\end{array}$ & $\begin{array}{c}\text { Human } \\
\text { figures } \\
\text { not pre- } \\
\text { sent }\end{array}$ & Total & $\begin{array}{l}\text { Human } \\
\text { figures } \\
\text { present }\end{array}$ & $\begin{array}{c}\text { Human } \\
\text { figures } \\
\text { not pre- } \\
\text { sent }\end{array}$ & Total \\
\hline \multirow{2}{*}{ Boys } & 38 & 126 & 164 & 63 & 65 & 128 \\
\hline & 23.17 & 76.83 & 100 & 49.22 & 50.78 & 100 \\
\hline \multirow{2}{*}{ Girls } & 71 & 131 & 202 & 74 & 66 & 140 \\
\hline & 35.15 & 64.85 & 100 & 52.85 & 47.15 & 100 \\
\hline \multirow{2}{*}{ Total } & 109 & 257 & 366 & 137 & 131 & 268 \\
\hline & 29.78 & 70.22 & 100 & 51.12 & 48.88 & 100 \\
\hline
\end{tabular}

Reviewing the Table 1, the drawings of child figure express unpleasant emotions in $29.78 \%$ of drawings, but pleasant emotions in $51.12 \%$ cases. $70.22 \%$ of children expressed unpleasant emotions without human figure, but pleasant in $48.88 \%$ cases. 
According to results of $\mathrm{x}^{2}$ test it is established that at importance level of .05 there are statistically important differences at expression of unpleasant emotion between boys and girls in relation to presence of human figures on drawings.

At girls, the human figures are present more than at boys, which points that girls in most cases accept their social environment and people and have no fear of adults.

\section{CONCLUSION}

Survey results point that there are important differences in expression of unpleasant emotions through drawing between boys and girls. Practically, on the results basis the contents can be programmed with both sexes children with use of drawings for emotion evaluation and examination of children emotional experiences.

\section{REFERENCES}

Pedagoška enciklopedija 1. (1989): 80. Srbija, Beograd: Zavod za udžbenike i nastavna sredstva.

Pogačnik-Tolčić S. (1964). Dječiji crtež kao izraz duševnog razvoja djeteta. Srbija, Beograd: Rad. 